Environment Conservation Journal 14(3) 33-40, 2013

ISSN 0972-3099 (Print) 2278-5124 (Online)

Abstracted and Indexed

\title{
Seasonal variation in ground water quality in and around Integrated Industrial Estate (IIE) Haridwar, India
}

\author{
D.R. Khanna, R. Bhutiani $\bowtie$ and Dipali Bhaskar Kulkarni
}

Received: 17.08.2013

Accepted: 28.10.2013

\begin{abstract}
A total of eighteen groundwater sources were sampled over a year to study physico-chemical properties and heavy metal content of ground water in and around the integrated industrial estate of Haridwar. Study area included locations with in approximately $5 \mathrm{kms}$ around the industrial area. Samples taken were representative of different land uses including the ecosensitive zone of Rajaji National park. Ground water quality in the study area exceeds permissible standard limits for conductivity, hardness, alkalinity, nitrate, total solids and total dissolved solids at some locations. Total alkalinity in the study area was found to be maximum in summer $(574.67 \mathrm{mg} / \mathrm{l})$ at the Railway station area and minimum $(85.33 \mathrm{mg} / \mathrm{l}) \mathrm{in}$ rainy season. Nitrate levels were found to be maximum in winter $(1291.61 \mathrm{mg} / \mathrm{l})$ at the rural area. Chloride level in the study area was found to range from a minimum $(12.67 \mathrm{mg} / \mathrm{l})$ in summer to a maximum $(169.33 \mathrm{mg} / \mathrm{l})$ in winter. Highest sulphate level $(192.67 \mathrm{mg} / \mathrm{l})$ was recorded at the rural area. Chromium and iron levels were found to exceed standard limits at almost all locations in the study area.
\end{abstract}

Keywords: water quality, integrated industrial estate,

\section{Introduction}

Growth of India's economy is led by a robust performance of the industrial sector. The development of a diversified industrial structure, based on a combination of large and small-scale industries, along with growing population has also contributed to the growing incidence of environmental pollution. Industrialization has significant environmental consequences in terms of ground water pollution especially as ground water is the resource most exploited by industrialization. In India, 56 per cent of metropolitan, class-I and class-II cities are dependent on groundwater, either fully or partially. Increasing demand and withdrawal, significant changes in land use pattern and vast industrial effluent entering the hydrological cycle stresses the quality and quantity of groundwater (Mackey, 1990).Water pollution is a serious problem in India as almost 70 per cent of its surface water resources and a growing percentage of its groundwater reserves are contaminated by biological, toxic, organic and inorganic pollutants. Besides rapidly depleting groundwater table, the country faces another major

\section{Author's Address}

Department of Zoology and Environmental Science, Gurukula

Kangri University, Haridwar

Email: rbhutiani@gmail.com problem on the water front - groundwater contamination. Urbanization, Industrialization, agro related practices coupled with improper disposal of solid waste, leaching from landfills and garbage pits transports toxic substances and heavy metals to the water table (SOE, India 2009). Most of the industries discharge their effluent without proper treatment into nearby open pits or pass them through unlined channels, resulting in the contamination of groundwater (Jinwal \& Dixit, 2008). One of the main objectives behind the creation of the separate state of Uttarakhand was to ensure rapid economic development of the area. Following its new industrial policy of 2003, Uttaranchal has achieved an impressive industrial growth rate of 18.18 percent in 2006 as compared to the national growth rate of 10.1 percent. Besides being a tourist hub, the holy city of Haridwar is now emerging as a key industrial destination of north India due to the presence of the Integrated Industrial Estate (IIE) established by SIDCUL, Uttarakhand in year 2000.It has been more than a decade since establishment of IIE Haridwar.This paper establishes and assesses the baseline water quality in IIE Haridwar and within a radius of approximately $5 \mathrm{kms}$ of the industrial area. 


\section{Study area}

Haridwar, one of the oldest living cities of India, in Haridwar district of Uttaranchal is located at a distance of 225 kms Northeast from Delhi, 52 kms from Dehradun and $494 \mathrm{kms}$ from Lucknow.It is the largest city and headquarters of Haridwar district and extends from latitude $29^{\circ} 58^{\prime}$ in the north to longitude $78^{\circ} 13^{\prime}$ in the east. The city grew between the Shivalik Mountain Range in the North and Northeast and Ganga River in the South. IIE, Haridwar established by SIDCUL in year 2000 is spread over 2034 acres and houses more than 585 industrial units. The industrial area houses a mix of pharmaceutical, plastics and allied, electrical and electronics, metal and fabrication, food and agro, textiles, paper and packaging, chemicals and general manufacturing industries etc. To enable holistic assessment of ground water quality; ground water from different land use areas in and around the industrial area was monitored. Map 1 shows the study area.

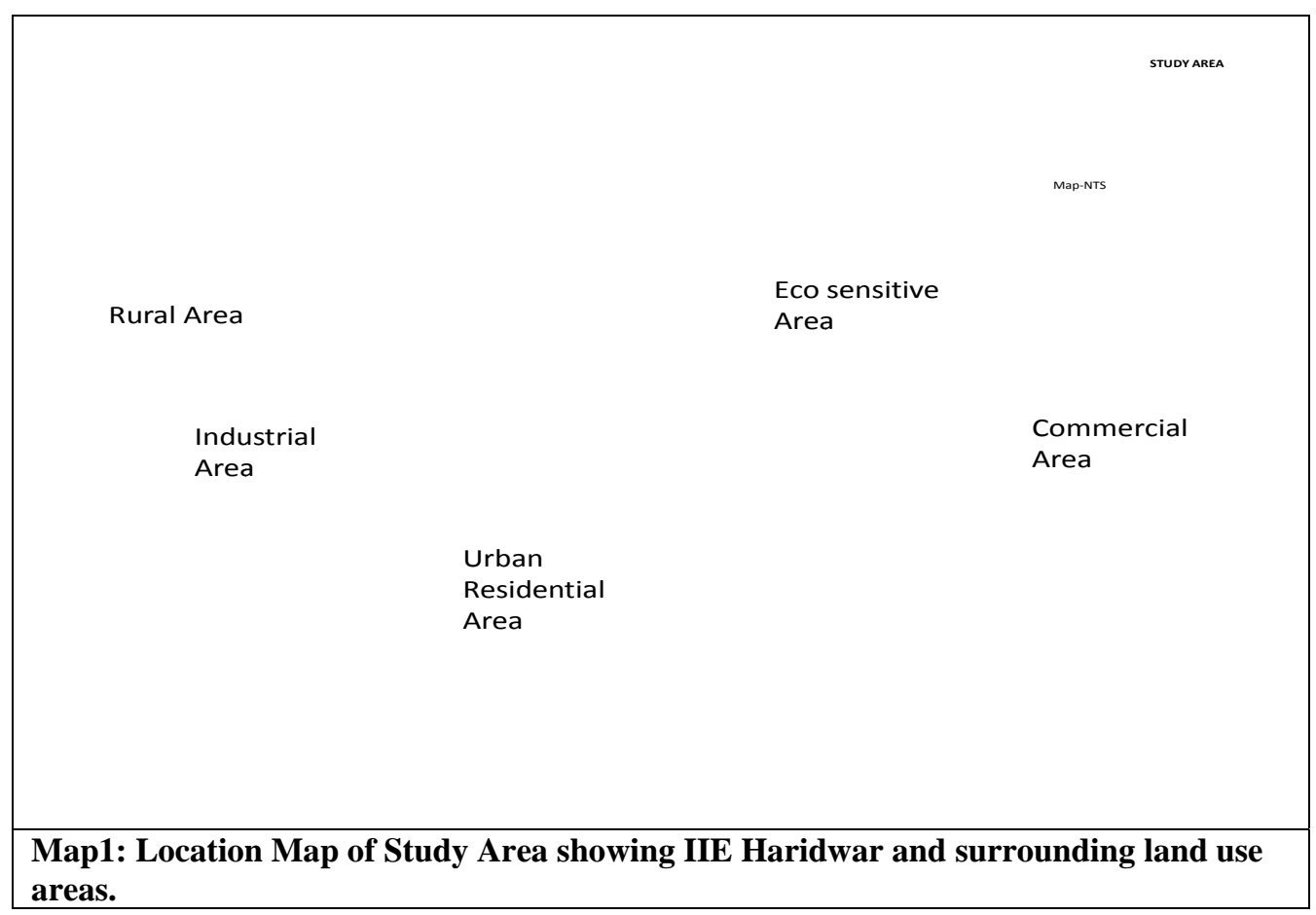

\section{Material and methods}

A total of eighteen groundwater sources (hand pumps, wells and tube wells) in and around Integrated Industrial Area (IIE) Haridwar were sampled and analyzed monthly for a year starting Jan 2012 to Dec 2012. Three groundwater sources were sampled from each of the six locations monthly amounting to a total of 216 samples.Groundwater was monitored for $\mathrm{pH}$, Temperature $\left({ }^{\circ} \mathrm{C}\right)$, Conductivity ( $\mu$ mhos/cm), TDS (mg/l) , TSS (mg/l), Alkalinity (mg/l), Total hardness (mg/l), calcium hardness (mg/l), magnesium hardness (mg/l), chloride (mg/l), Sulphate $(\mathrm{mg} / \mathrm{l})$ and Nitrate $(\mathrm{mg} / \mathrm{l})$. Samples were also analyzed for heavy metals Chromium (mg/l),Cobalt(mg/l),Nickel(mg/l),Zinc (mg/l) and
Iron (mg/l) .All samples were collected and analyzed as per Standard methods of examination of water and waste water, APHA (1998.Water temperature was measured with mercury thermometer,pH with $\mathrm{pH}$ meter, TDS and conductivity with TDS and conductivity meter. Hardness was measured titrimetrically by EDTA method while Alkalinity was also measured titrimetrically. Total Solids and TSS were measured by gravimetric method. Sulphate and Nitrate were measured with spectrophotometer by turbidimetric method and Brucine method respectively. Heavy metals were detected from digested samples using Atomic Absorption Spectrophotometer. Statistical analysis was carried out using SPSS 21 and MS Excel. 


\section{Results and discussion}

Table 1 and figure 1 show the season wise physicochemical characteristics and status of heavy metals in groundwater of the study area.Temperature is basically important for its effect on chemical and biological reaction in the organisms living in water (Chapolikar et al. 2010). Ground water temperature was found to be minimum in winter at $16.03^{\circ} \mathrm{C}$ and maximum in summer at $37.97^{\circ} \mathrm{C} . \mathrm{pH}$ in the study area was found to range between 6.3 and 7.97. $\mathrm{pH}$ was found to be within the acceptable standard range of 6.5 to 8.5 as prescribed by BIS 105000 . Gaur et al. (2011) reported that $\mathrm{pH}$ in ground water of Haridwar region showed no remarkable variation from BIS recommended value of $\mathrm{pH}$. Maximum $\mathrm{pH}$ was observed in winter and minimum in monsoon season. Electrical conductivity of water is directly related to the concentration of dissolved ionized solids in the water. Ions from the dissolved solids in water create the ability for that water to conduct an electrical current, which can be measured using a conductivity meter. Water with high mineral content tends to have higher conductivity, which is a general indication of high dissolved solid concentration of the water (Mumtazuddin et al. 2012).Conductivity in the study area ranged from a minimum of $272.67 \mu \mathrm{mhos} / \mathrm{cm}$ to a maximum of $1143.33 \mu \mathrm{mhos} / \mathrm{cm}$ in rainy season. B.Balaji et al. (2013) reported highest value of conductivity during monsoon indicating high amount of dissolved inorganic substances in ionized form.Maximum conductivity in ground water was observed in the rural agricultural area while groundwater in the eco-sensitive area of Rajaji national park had minimum conductivity. Hardness is most commonly associated with the ability of water to precipitate soap. Chemically, hardness is often defined as the sum of polyvalent cation concentrations dissolved in the water, the most commonly considered polyvalent cations being calcium $(\mathrm{Ca}++)$ and magnesium $(\mathrm{Mg}++)$.Total hardness was found to range between $112 \mathrm{mg} / \mathrm{l}$ and 954mg/l. Calcium hardness ranged from a minimum of $37.41 \mathrm{mg} / \mathrm{l}$ to a maximum of 680.02 $\mathrm{mg} / \mathrm{l}$ in summer in the study area. Magnesium hardness in groundwater of the study area ranged from a minimum of $23.49 \mathrm{mg} / \mathrm{l}$ in winter to a maximum of $500.57 \mathrm{mg} / \mathrm{l}$ in summer. Hardness values were observed to be highest in summer season. Groundwater in rural area had maximum hardness. According to classification of water based on hardness, hardness in the study area ranges from moderately hard to very hard. Alkalinity represents the buffering capacity of water and its ability to resist a change in $\mathrm{pH}$. Alkalinity is the sum of primarily bicarbonate, carbonate, and hydroxide ions in water that tend to elevate the $\mathrm{pH}$ of the water above 4.5 . These factors are characteristic of the source of water, geological formation and the natural processes taking place at any given time and provide an idea of the nature of salts present in the water. Bicarbonate represents the major form of alkalinity. Total Alkalinity in the study area was found to be maximum in summer $(574.67 \mathrm{mg} / \mathrm{l})$ at the Railway station area and minimum at 85.33 $\mathrm{mg} / \mathrm{l}$ in rainy season. Nitrate level was found to be maximum in winter $(1291.61 \mathrm{mg} / \mathrm{l})$ at the rural area. High nitrate levels in rural area are likely to result from anthropogenic sources including septic systems, manure storage facilities and land application of manure and fertilizers in addition to geologic conditions. Liyanage et al. (2000) nitrates resulting from these activities can leach from the surface to underlying aquifers, resulting in elevated nitrate concentrations. Minimum nitrate level observed was $1.12 \mathrm{mg} / \mathrm{l}$ in winter at the Rajaji National park. Nitrate levels were found to exceed the standard acceptable level of $45 \mathrm{mg} / \mathrm{l}$ (Nitrate as $\mathrm{NO}_{3}$ ) all land use locations except the Rajaji National Park. Chloride level in the study area was found to range from a minimum of $12.67 \mathrm{mg} / \mathrm{l}$ in summer to a maximum of $169.33 \mathrm{mg} / \mathrm{l}$ in winter. Chloride level was found to be maximum in the old industrial area. High chloride content in ground water can be attributed to natural processes such as the passage of water through natural salt formations in the earth or it may be an indication of pollution from industrial sources. Swaranlatha and Narsinga Rao (1998) and Mukul et al. (2007) reported similar findings.Chloride levels in the study area were well below the standard permissible value of $250 \mathrm{mg} / \mathrm{l}$. An important source of sulphate in groundwater is the oxidation of pyrite (ferrous sulphide) which is widely distributed in sedimentary rocks. Sulphates are discharged into water from wastes from industries that use sulphates and sulphuric acid, such as mining and smelting operations, kraft pulp and paper mills, textile mills and tanneries etc. The major 
physiological effects resulting from the ingestion of Sulphate level in the study area ranged from a large quantities of sulphate are catharsis and minimum of $0.14 \mathrm{mg} / \mathrm{l}$ in winter to a maximum of gastrointestinal irritation. $192.67 \mathrm{mg} / \mathrm{l}$ in summer.

Table 1: Physico-chemical properties and heavy metal content of ground water in study area

\begin{tabular}{|c|c|c|c|c|c|c|c|c|c|}
\hline \multirow[t]{2}{*}{ S.No } & \multirow[b]{2}{*}{ Parameter } & \multicolumn{2}{|c|}{ Winter(W) } & \multicolumn{2}{|c|}{ Summer(S) } & \multicolumn{2}{|c|}{ Rainy(R) } & \multicolumn{2}{|l|}{ BIS 10500} \\
\hline & & $\min$ & $\max$ & $\min$ & $\max$ & $\min$ & $\max$ & Desirable & Permissible \\
\hline 1 & $\operatorname{Temp}\left({ }^{\circ} \mathrm{C}\right)$ & 16.03 & 29.37 & 21.03 & 37.97 & 23.01 & 34.03 & & \\
\hline 2 & $\mathrm{pH}$ & 6.90 & 7.97 & 6.51 & 7.81 & 6.30 & 7.79 & $6.5-8.8$ & No relaxation \\
\hline 3 & $\begin{array}{l}\text { Conductivity } \\
(\mu \mathrm{mhos} / \mathrm{cm})\end{array}$ & 304.98 & 1107.67 & 289.67 & 1037.31 & 272.67 & 1143.33 & -- & -- \\
\hline 4 & $\begin{array}{l}\text { Total } \\
\text { hardness(mg/L) }\end{array}$ & 112.00 & 877.33 & 129.33 & 954.67 & 141.33 & 665.33 & 300 & 600 \\
\hline 5 & $\begin{array}{l}\text { Calcium } \\
\text { hardness(mg/L) }\end{array}$ & 88.18 & 622.58 & 37.41 & 680.02 & 41.42 & 486.30 & 75 & 200 \\
\hline 6 & $\begin{array}{l}\text { Magnesium } \\
\text { hardness(mg/L) }\end{array}$ & 35.73 & 479.59 & 31.45 & 500.57 & 23.49 & 295.49 & 30 & 100 \\
\hline 7 & Alkalinity(mg/L & 104.00 & 414.67 & 93.33 & $\mathbf{5 7 4 . 6 7}$ & 85.33 & 369.33 & 200 & 600 \\
\hline 8 & Nitrate(mg/L) & 1.12 & 1145.32 & 1.12 & 203.44 & 2.99 & 1291.61 & 45 & 100 \\
\hline 9 & Chloride(mg/L) & 14.00 & 169.33 & 12.67 & 156.00 & 20.67 & 151.33 & 250 & 1000 \\
\hline 10 & Sulphate(mg/L) & 0.14 & 66.52 & 0.14 & 192.67 & 1.00 & 68.29 & 200 & 400 \\
\hline 11 & TS(mg/L) & 361.00 & 1201.00 & 320.67 & 1203.33 & 300.67 & 1399.33 & --- & --- \\
\hline 12 & TDS(mg/L) & 204.33 & 718.67 & 193.67 & 695.00 & 176.67 & 740.67 & 500 & 2000 \\
\hline 13 & TSS(mg/L) & 32.00 & 739.33 & 39.33 & 761.33 & 22.33 & 895.67 & --- & --- \\
\hline 14 & $\mathrm{Co}(\mathrm{mg} / \mathrm{L})$ & $\mathrm{BDL}$ & 2.84 & BDL & 3.13 & BDL & 3.03 & --- & --- \\
\hline 15 & $\mathrm{Cr}(\mathrm{mg} / \mathrm{L})$ & $\mathrm{BDL}$ & 2.49 & $\mathrm{BDL}$ & 2.05 & $\mathrm{BDL}$ & 1.94 & 0.05 & No relaxation \\
\hline 16 & Nickel(mg/L) & $\mathrm{BDL}$ & 1.28 & $\mathrm{BDL}$ & 1.77 & $\mathrm{BDL}$ & 1.63 & --- & --- \\
\hline 17 & $\mathrm{Zn}(\mathrm{mg} / \mathrm{L})$ & BDL & 2.12 & $\mathrm{BDL}$ & 1.82 & $\mathrm{BDL}$ & 1.78 & 5 & No relaxation \\
\hline 18 & $\mathrm{Fe}(\mathrm{mg} / \mathrm{L})$ & $\mathrm{BDL}$ & 1.38 & BDL & 1.90 & $\mathrm{BDL}$ & 1.88 & 0.3 & 1 \\
\hline
\end{tabular}

Highest sulphate level was recorded at the rural TDS in groundwater are generally not harmful to area.The presence of high concentration of human beings but high concentration may affect sulphates can be attributed the discharge of persons, who are suffering from kidney and heart domestic sewage and littering of organic wastes in diseases (Gupta, et al, 2004).Total Suspended the region (D. Loganathan et al. 2011). Sulphate levels in the study area were below the standard value of $200 \mathrm{mg} / \mathrm{l}$. All natural waters contain some dissolved solids due to the dissolution and weathering of rock and soil. Total solids in the study area ranged from a minimum of $300.67 \mathrm{mg} / \mathrm{l}$ to a maximum of $1399.33 \mathrm{mg} / \mathrm{l}$ in rainy season. TS level was maximum at the old industrial area. TDS levels in the study area ranged from a minimum of $176.67 \mathrm{mg} / \mathrm{l}$ in monsoon to a maximum of 740.67 $\mathrm{mg} / \mathrm{l}$ in the same season. Highest TDS was recorded at the rural location. Conductivity and TDS being highly correlated parameters; recorded highest concentrations at the same location. High values of

solids in groundwater ranged from a minimum of $22.33 \mathrm{mg} / \mathrm{l}$ to a maximum of $895.67 \mathrm{mg} / \mathrm{l}$ in monsoon. Heavy metals are chemical elements with a specific gravity at least 5 times that of water. The specific gravity of water is 1.0 at $4^{\circ} \mathrm{C}\left(39^{\circ} \mathrm{F}\right)$. When water is contaminated with these heavy metals it becomes toxic and dangerous for human biological system (APHA, 1998). Trace elements are easily influenced by environmental factors such as surface runoff, groundwater, dissolution from sediment, deposition from the atmosphere and anthropogenic pollutants.Municipal and industrial wastes and effluents are primary sources of anthropogenic cobalt inthe environment. 
Seasonal variation in ground water quality
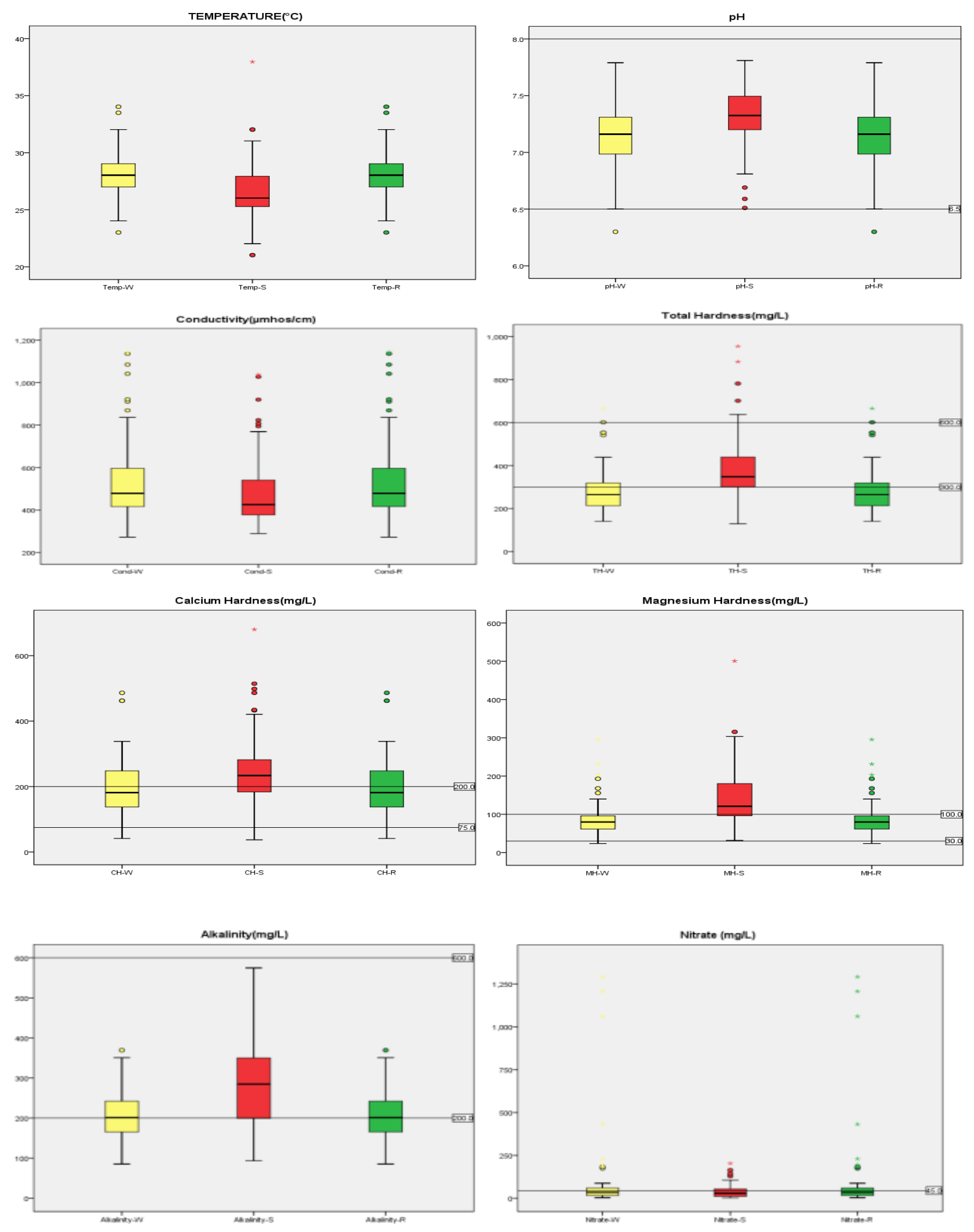
Khanna et al.
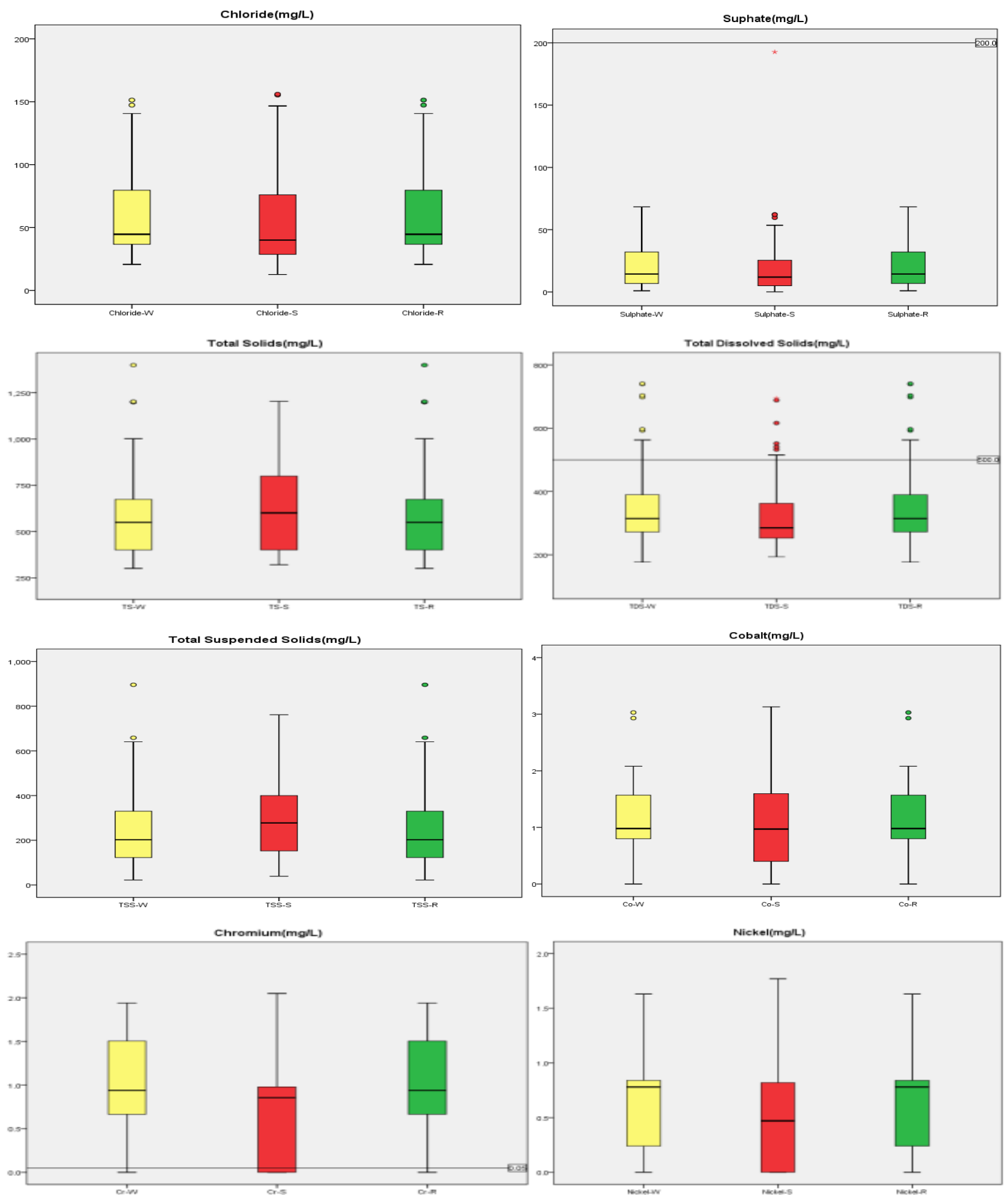

Fig 1: Box plots showing seasonal variation in groundwater quality in the study area

\begin{tabular}{|l|l|l|}
\hline WINTER & SUMMER & RAINY \\
\hline
\end{tabular}


Cobalt is used in magnets to increase the saturation of magnetization of iron. It is also used as a pigment in glass, ceramics, and paints; as paint drier; as a catalyst for the petroleum industry; and in batteries. Many fertilizers are enriched with cobalt, to amend cobalt-deficient agricultural soils. Municipal and industrial wastes and effluents are primary sources of anthropogenic cobalt in the environment. Maximum level of Cobalt was found to be $3.13 \mathrm{mg} / \mathrm{L}$ in summer at the commercial area. Chromium is used in metal alloys and pigments for paints, cement, paper, rubber, and other materials. Low-level exposure can irritate the skin and cause ulceration. It is carcinogenic and causes respiratory problems. Long-term exposure can cause kidney and liver damage, and damage to circulatory and nerve tissue. The maximum concentration of Chromium in the study area was $2.49 \mathrm{mg} / \mathrm{l}$ in winter at the rural area which is more than the permissible limit of $0.05 \mathrm{mg} / \mathrm{l}$. Chromium levels were found to exceed standard limits at all landuse areas in one season or the other. Gaur et al. (2011) reported high chromium levels in groundwater of Haridwar region. The primary source of nickel in drinking-water is leaching from metals in contact with drinking-water, such as pipes and fittings. However, nickel may also be present in some ground waters as a consequence of dissolution from nickel ore-bearing rocks. Nickel concentrations in groundwater depend on the soil use, $\mathrm{pH}$, and depth of sampling (WHO, 2007).Nickel level in the study was found to be maximum at $1.77 \mathrm{mg} / \mathrm{l}$ in summer at the rural location. The WHO prescribes a standard level of $0.5 \mathrm{mg} / \mathrm{l}$ in drinking water.It is used principally for galvanizing iron and steel, in electric batteries and for roofing and gutters in building construction. Most zinc is added in the environment during industrial activities, such as mining, coal and waste combustion and steel processing. Although humans can handle proportionally large concentrations of zinc, too much zinc can still cause eminent health problems, such as stomach cramps, skin irritations, vomiting, nausea and anaemia. The maximum level of zinc recorded was $2.12 \mathrm{mg} / \mathrm{l}$ in IIE Haridwar in winter season .Zinc levels in the study area were found to be within the acceptable standard value of $5 \mathrm{mg} / \mathrm{l}$ as per BIS 105000 (1991). Iron is the second most abundant metal in the earth's crust, of which it accounts for about 5\%.Elemental iron is rarely found in nature, as the iron ions $\mathrm{Fe} 2+$ and $\mathrm{Fe} 3+$ readily combine with oxygen- and sulfur-containing compounds to form oxides, hydroxides, carbonates, and sulfides. Iron is most commonly found in nature in the form of its oxides. Iron levels of about $2 \mathrm{mg} /$ are not likely to present a hazard to human health. (WHO,2003). Maximum Iron level of 1.9 $\mathrm{mg} / \mathrm{L}$ was recorded in the study area in summer and exceeds the desirable standard value of 0.3 $\mathrm{mg} / \mathrm{L}$ as per Indian standards for drinking water BIS 105000(1991).

\section{Conclusions}

This paper establishes the baseline ground water quality in and around the Integrated Industrial Area (IIE) Haridwar and assesses range and seasonal variation. Ground water quality in the study area exceeds permissible standard limits for Conductivity, Hardness, Alkalinity, Nitrate, Total Solids and Total Dissolved Solids at some locations. Nitrate concentration was maximum in Rural area. The hardness of groundwater in the study area ranges between moderately hard to very hard. Nitrate concentrations were found to exceed standard limits at all the land use locations except the Rajaji National Park. Heavy metals concentration exceeds permissible standard limits for parameters Chromium and Iron. Deterioration of Groundwater quality parameters in the study area can be attributed to anthropogenic activities such as urban-industrial, agricultural activities taking place in the study area.

\section{References}

APHA (American Public Health Association) 1998. Standard method for examination of water and wastewater, 20th edition, Washington, DC, USA, P. 4.66-4.69.

B.Balaji Prasath,R.Nandakumar,S.Dinesh Kumar, S. Ananth, A. Shenbaga Devi, T. Jayalakshmi, P.Raju, M. Thiyagarajan and P Santhanam 2013. Seasonal variations in physico-chemical characteristics of pond and ground water of Tiruchirapali,India,Journal of Environmental Biology,Vol 34,529-537,May 2013.

BIS (Bureau of Indian Standards) 10500, 1991 Indian standard drinking water specification, First revision, 1-8.

Chapolikar A.D., Bharad J.V., Madje B.R. and Ubale M.B, 2010. Asian J. Research Chem, 3 (1) 102-105

Sawyer, C.N. and P.L. McCarty 1978 Chemistry for Environmental Engineering, 3rd ed., McGraw-Hill Book Company, New York. 
D. Loganathan, S. Kamatchiammal, R. Ramanibai1, D. Jayakar Santhosh, V. Saroja and S. Indumathi. 2011. Status of groundwater at Chennai city, India, Indian Journal of Science and Technology, Vol. 4 No. 5 (May 2011).

Gaur S, Joshi M.C, Saxena S.K and Dutt H.K. 2011. Analytical study of water safety parameters in ground water samples of Uttarakhand in India, Journal of Applied Pharmaceutical Science 01 (09):166-169

Gupta S, Kumar A, Ojha C.K and Singh G.J 2004. Environmental Science and Engineering. 46(1): 74-78.

Liyanage, C.E., M.I. Thabrew and D.S.P. Kuruppuarachchi, 2000. Nitrate pollution in groundwater of Kalpitiya: An evaluation of the content of nitrates in the water and food items cultivated in the area. J. National Scie. Foundation Sri Lanka, 28(2): 101-112.

Jinwal, A. and Dixit S. 2008. Pre and post monsoon variation in physio-chemicalcharacteristic in groundwater quality in Bhopal, India. Asian J. Exp. Sci. 22 (3), 311-316.

Mackey, R.1990. “Groundwater Quality" in: Thannah and Biswas,A.K (eds) Environmentally Sound Water Management, Oxford University Press.
Mukul Bisnoi and S.Arora, 2007. Potable ground water quality in some villages of Haryana, India: Focus on Flouride.J. Environ.Biol. 28,291-294.

Mumtazuddin S., Azad A.K.,Bharti Prabhat and Ranjan Rakesh 2012. Physico-chemical analysis of groundwater of the Budhi Gandak belt in Muzaffarpur district, India, I Research Journal of Environment Sciences, 1(1):7-11

SOE Report, India 2009. Ministry of Environment and Forests (MoEF).

Swaranlatha, S and A.N. Rao. 1998. Ecological studies of Banjara lake with reference to water pollution, $\boldsymbol{J}$. Environ.Biol. 19,179-186.

WHO, 2003. Zinc in Drinking water, Background document for development of WHO Guidelines for Drinking-water Quality,WHO/SDE/WSH/03.04/17

WHO, 2007. Nickel in Drinking water, Background document for development of WHO Guidelines for Drinking-water Quality,WHO/SDE/WSH/07.08/55. 